\title{
Effectiveness of Korean Classical Novels' Usage in an English as a Foreign Language Classroom
}

\author{
Park, Sang Young ${ }^{1}, \&$ McIver, Patrick ${ }^{1}$ \\ ${ }^{1}$ Korean Language Education, Daegu Catholic University, South Korea \\ Correspondence: Patrick McIver, Foreign language Education, Daegu Catholic University, Gyeongsan-si, \\ Gyeongbuk ROK, South Korea.
}

Received: January 13, 2022

Accepted: February 17, $2022 \quad$ Online Published: February 23, 2022

doi:10.5430/wjel.v12n1p236

URL: https://doi.org/10.5430/wjel.v12n1p236

\begin{abstract}
The current bilingual theories argue that the L2 language practices of bilingual students are derived from a single language repertoire and that enabling students to have access to their entire language repertoire can be an essential resource for further language development. Recent academic studies show that using students' language repertoire, including L1 language in the target language classroom, increases their intrinsic motivation and improves fluency; however, many researchers still show skepticism regarding this teaching pedagogy. Therefore, this research validates that using L1 text improves students' intrinsic motivation and fluency and increases curiosity about L2 culture while learning L2 language. In order to prove this, the study used three classical Korean novels written by Park Ji Won. The study included 98 students from intermediate and beginner speaking in an English as a Foreign Language (EFL) classes. A task-based assignment was given, and a questionnaire was used to ascertain the students' opinions on the use of L1 text to improve motivation, fluency, and curiosity. This study reveals that EFL students can acquire a second language by learning about their traditions and culture, not just a practical and utilitarian text. In addition, this research proves that increasing curiosity and knowledge are integral components in language development, not only with the L1 text but also congruent with the L2 text, which is essential to acquiring the target language. The implication of this study emphasizes that not only L2 texts but also L1 texts are crucial for language development.
\end{abstract}

Keywords: teaching pedagogy, L1 Korean classical novel, motivation, fluency, curiosity, interaction

\section{Introduction}

\subsection{Introduction of Problem}

Until the late 1960s, using one's mother tongue to learn a new language was considered a hindrance rather than a successful language acquisition strategy (Abrahamsson, 2009). Therefore, the thought that bilingualism is achieved through monolingual pedagogical approaches has become widespread, and this method has been extensively researched (Bialystok, 2001). Consequently, many teachers use only English in the classroom, expecting that the target language can be acquired naturally when it is the only medium of communication used without any interference. Many teachers also express concerns about using L1 languages as aids when English is insufficient. This is because they consider that using L1 text hinders students' development in English as a foreign language (EFL). Teachers who express this concern usually consider L1 languages confusing or harmful (Abiria et al., 2013; Ekman, 2015; Iannacci, 2008).

The traditional view of learning an L2 is that the target language should only be instructed to immerse students in the target language and culture. This approach is based on the notion that languages are cognitively compartmentalized and that bilingualism is achieved through monolingual pedagogical approaches (Bialystok, 2001). According to this belief, students are expected to behave as "two monolinguals in one."

Contrary to traditional approaches, a more flexible view that students' entire linguistic repertoire, instead of focusing on compartmentalization between languages, can be effectively used in EFL classrooms is gradually gaining prominence (Cummins, 2017; Garcia \& Li, 2014; Garcia \& Seltzer, 2016; Heinzmann \& Hoti, 2012; Karlsson et al., 2016; Mazak \& Carroll, 2017; Moore, 2016). Cook (2001, pp. 407-408) and Cimbganda and Mokgwathi (2012, p. 21 ) found that perceiving languages as separate compartments of learning fails to recognize students' abilities and previous knowledge, arguing that this might inhibit their language learning as they might not use their entire 
linguistic repertoire.

Scholars in the field of bilingualism have addressed the language separation pedagogy in immersion or dual-language programs, as well as students' dynamic use of their skills and metalinguistic knowledge, to facilitate the achievement of successful communication measured by bilingual standards (Gort, 2006; Gort \& Pontier, 2013; Lee, 2007; Manyak, 2006; Varghese, 2008). Researchers have also studied the various functions fulfilled by students' L1 languages in the L2 language acquisition process in these contexts (DiCamilla \& Antón, 2012; Storch \& Wigglesworth, 2003; Swain \& Lapkin, 2000).

As stated above, the debate regarding the two-pedagogy approach has become the forefront with the following question: "Is the use of the L1 (text and language) in an EFL classroom beneficial to the students to enhance their fluency ability and foster their curiosity?" Despite the recent recognition of the importance of L1 text usage in EFL classrooms, many scholars have indicated that adopting plurilingualism in actual classrooms is not a straightforward practice as its implementation is challenging (Boeckmann, 2012). One of the main reasons for this is the differences among societies and educational contexts, depending on their specific characteristics. However, focusing on plurilingualism in actual classrooms to improve students' learning development is inevitable, since the pedagogical shift from monolingualism to plurilingualism has become a considerable challenge in the education field.

Therefore, this study aims to clarify the pedagogical effectiveness of using L1 text in an L2-language-learning EFL university classroom, as it correlates with improving students' intrinsic motivation, fluency, discourse, and increasing curiosity, primarily through the use of Korean classical novels. Since the importance of L1 text in a classroom as an aid to L2 language learning has been extensively emphasized, many teachers have shown their interest in this; however, no authentic use of L1 text in a classroom has been practically implemented, and the effectiveness of L1 text is presented mainly from teachers' viewpoint, not from students' viewpoint. However, students' viewpoint is critical because it can provide a balanced perspective in the field, which has been studied from a teacher-centered perspective, and can effectively solve interactive representations of problem-based assignments.

\subsection{Purpose of Research}

The significance of a multidimensional study using Korean classical novels is based on the conviction that the novels can offer the learners authentic and sociocultural perspectives on society and moral values, which is something beyond the narrow focus of language teaching. This potentially crucial pedagogical factor has been ignored in EFL programs, whose central aim is to achieve linguistic proficiency (McIver \& Park, 2020). Previous studies have focused on teachers' perspectives and opinions or used students' interviews without providing them with an opportunity to use authentic L1 text in a classroom (Alsaawi, 2020; Tabatabaei, 2019). In contrast, this study uses authentic L1 text and provides students the opportunity to express their opinion through a five-point Likert-scale questionnaire and class discussion. Given this background, this study focuses on the following research questions (RQs):

RQ1. How does the use of L1 text (Korean classical novels) and language in an EFL classroom affect students' intrinsic motivation and fluency of the L2 language?

RQ2. How does the use of L1 text (Korean classical novels) and language in an EFL classroom increase students' curiosity about the language and culture of the L2 language?

\section{Methodology}

This article adopts a quantitative research methodology, which was designed to measure students' attitudes in terms of motivation, fluency, and curiosity toward the L2 language and culture. Following Bronfenbrenner and Morris' (1998) model, this research included learners from six beginner and six intermediate (class titles Intermediate \& Beginner Speaking) English classes; the students were enrolled in a compensatory practical English (EFL) class comprising only South Korean university learners from grade first to fourth. All students attended Daegu Catholic University and signed a release form that allowed the answers to be used in the study.

The questionnaire provided insight into the instructional pedagogical uses of L1 text.

This study used three well-known Korean classical novels from Park Ji-Won, a famous 18th-century author, as L1 text. The first novel was Yangbanjeon, a representative novel revealing yangban's (upper class's) hypocrisy by drawing up a document of yangban's certificate between a wealthy merchant and poor yangban. This novel reflects the shaky social status system in the late Chosen Dynasty (18th-century South Korea).

The second novel was HeoSaengjeon, which presents various contradictions of the social structure of the time (the hypocrisy of politicians stained with pretentiousness and the fragility of the economic structure, such as commercial 
exchange) in a multifaceted manner through the activities of a capable scholar, Heosang. This novel is well-known for its satirical and realistic tendencies with the importance of practical thinking (so-called Silhak).

The final novel was Hojil, which involves a corrupt and hypocritical yangban Buk-gwak (北郭) and a promiscuous widow, Donglija, with children from different fathers. They are revered as a respected scholar and a devotee, respectively, on the surface. While enjoying their sex life secretly, they are caught by Donglija's sons. Then, Buk-gwak fights in a row and falls into a pile of dung, and a tiger passing by gets upset and scolds Buk-gwak. This novel also satirizes and strongly criticizes a part of society during the reign of the Choseon Dynasty.

These novels had significant social implications during the Choseon Dynasty and can be applied to today's societies worldwide. This is the reason why these novels were selected in this study; they are expected to provide an academic foundation for developing problem-based assignments. The students were divided into three groups during the class. First, each group received one of the three novels (Group 1: Yangbanjeon, Group 2: HeoSaengjeon, and Group 3: Hojil). The students were then assigned the following tasks (Table 1):

Table 1. Problem-based Assignments

\begin{tabular}{ll}
\hline Problem-based Assignments & Number of Students \\
\hline Synopsis & 1 or 2 students \\
Identify social implications & group \\
Class discussion & group \\
\hline
\end{tabular}

L1 text and the three problem-based assignments were designed to provide an opportunity to discuss real-world problems and support student learning of concepts and principles instead of the simple concept that we see in most L2 textbooks. The problem-based assignments were a synopsis of the novel, identify social impact and class discussion. In contrast to a simple L2 language, these problem-based assignments promote student learning concepts and principles. Through students' understanding of the text and drawing on the knowledge of their L1 lexicon, we found correlations among increasing motivation, improving fluency, increasing curiosity, and improving discourse.

The students were notified of the problem-based assignments one week before the class. The L1 classical novels were posted on the learning management system. The student sample size for this research is shown in Table 2.

Table 2. Distribution of Sample Groups by Gender

\begin{tabular}{lrl}
\hline Gender & Number of Students & Percent \\
\hline Male & 61 & $61 \%$ \\
Female & 33 & $33 \%$ \\
Prefer not to state & 4 & $4 \%$ \\
\hline Total & 98 & $100 \%$ \\
\hline
\end{tabular}

Table 2 shows the distribution of the sample by gender. Over 98 respondents participated in the survey, of whom 61 were male, 33 were female, and 4 preferred not to state their gender.

\section{Data Analysis and Results}

The five-point Likert scale questionnaire used in this study contained 18 individual questions that specifically measured the students' attitudes toward the use of Korean classical novels in an EFL/ESL classroom. Quantitative data were analyzed using the Statistical Package for the Social Sciences program, which was used to calculate descriptive statistics and Pearson correlation coefficients. The test of normality was used to examine the relationship between the uses of Korean classical novels (L1), as it relates to student motivations, improving fluency, increasing interaction between L1 and L2, and increasing curiosity in learning a second language and its culture. This report, therefore, describes the results for individual items in the 18-item Likert scale questionnaire.

\subsection{Validation of the Questionnaire}

Cronbach's alpha coefficient was used to assess the internal consistency and reliability of the questionnaire. Building on the validation of the questionnaire, it was imperative to ensure the reliability, usability, and understanding of the items for EFL students (Dawson et al., 2011). In addition, the questionnaire was translated into Korean (by a professor in the Korean language education department) to ensure better understanding of the students and exclude 
any chance of confusion about the individual questions. The results are shown in Table 3.

Table 3. Cronbach

\begin{tabular}{lll}
\hline & $\mathrm{n}$ & $\mathrm{a}$ \\
\hline Avg. & 18 & 0.82 \\
\hline
\end{tabular}

The items on the questionnaire reported an overall Cronbach's alpha of 0.82 , thereby demonstrating acceptable internal consistency.

\subsection{Statistical Analysis}

For the questionnaire, descriptive statistics, Pearson correlation, and a normality test were adopted to determine whether there were statistical differences among the students in terms of the use of L1 classical novels based on the level of English (intermediate or beginner) and gender. In addition, these tests were used to determine if statistical differences existed between the groups (Cohen, 1988).

The class's overall descriptive statistics for RQ1 (motivation/fluency) were motivation $\mathrm{M}=3.76, \mathrm{SD}=.600$ and fluency $\mathrm{M}=3.63, \mathrm{SD}=.776$. For RQ2 (curiosity/interaction), the descriptive statistics' overall mean for curiosity was $\mathrm{M}=3.40, \mathrm{SD}=.502$ and that for interaction was $\mathrm{M}=3.75, \mathrm{SD}=.652$. However, in terms of gender, there were no differences (for a complete breakdown of the means and standard deviations, see Table 4).

Table 4. Descriptive Statistics

\begin{tabular}{|c|c|c|c|c|c|c|c|}
\hline & Class & Mean & Std. Dev. & & Gender & Mean & Std. Dev. \\
\hline \multirow{4}{*}{ Motivation } & Intermediate & 4.01 & .348 & \multirow{4}{*}{ Motivation } & Male & 3.79 & .588 \\
\hline & Beginner & 3.46 & .689 & & Female & 3.66 & .643 \\
\hline & Overall & 3.76 & .600 & & Prefer not to state & 4.10 & .200 \\
\hline & & & & & Overall & 3.76 & .600 \\
\hline \multirow{4}{*}{ Fluency } & Intermediate & 4.02 & .399 & \multirow{4}{*}{ Fluency } & Male & 3.68 & .684 \\
\hline & Beginner & 3.20 & .867 & & Female & 3.47 & .910 \\
\hline & Overall & 3.63 & .776 & & Prefer not to state & 4.31 & .590 \\
\hline & & & & & Overall & 3.63 & .776 \\
\hline \multirow{4}{*}{ Interaction } & Intermediate & 4.02 & .447 & \multirow{4}{*}{ Interaction } & Male & 3.67 & .614 \\
\hline & Beginner & 3.44 & .709 & & Female & 3.81 & .701 \\
\hline & Overall & 3.75 & .652 & & Prefer not to state & 4.43 & .426 \\
\hline & & & & & Overall & 3.75 & .652 \\
\hline \multirow{4}{*}{ Curiosity } & Intermediate & 3.63 & .343 & \multirow{4}{*}{ Curiosity } & Male & 3.36 & .489 \\
\hline & Beginner & 3.15 & .535 & & Female & 3.38 & .428 \\
\hline & Overall & 3.40 & .502 & & Prefer not to state & 4.20 & .163 \\
\hline & & & & & Overall & 3.40 & .502 \\
\hline
\end{tabular}

Table 4 shows the mean and standard deviation by class and gender; however, when combining the variables, we could see an intermediate class with $\mathrm{M}=3.92$ and $\mathrm{SD}=.434$, while the beginner class had $\mathrm{M}=3.31$ and $\mathrm{SD}=.700$. Thus, while both classes supported the L1 text in the class, the intermediate class agreed more with the L1 text in an EFL/ESL classroom. In terms of gender, males presented $\mathrm{M}=3.62, \mathrm{SD}=.593$ and females presented $\mathrm{M}=3.58, \mathrm{SD}$ $=.670$, showing that both males and females supported the use of L1 text in an EFL/ESL class with a very slight difference in their means.

\subsection{Inferential Analysis}

For the normality test, one of the expectations is that the variable scores should be symmetrical or indicate a bell-shaped curve - with the most significant frequency of scores distributed in the middle and minor frequencies distributed toward the extremes. For the current task, Kolmogorov-Smirnov's and Shapiro-Wilk's normality tests were used to assess the normality assumption for the variables. This test was completed under the hypothesis that motivation, fluency, and curiosity of L2 culture scores are normally distributed.

The results illustrated in Table 5 show a significant departure from a normal distribution ( $\mathrm{p}$-value $=0.000$; rejects the null hypothesis that the data originate from a normal population). The normality assumption was not reasonable for any of the given variables. An expected result shows that the motivation, fluency, and curiosity of the L2 culture scores are not normally distributed. 
Table 5. Normality Test

\begin{tabular}{lllllll}
\hline & \multicolumn{2}{l}{ Kolmogorov-Smirnov $^{\mathrm{a}}$} & & \multicolumn{2}{l}{ Shapiro-Wilk } & \\
\hline & Statistic & df & Sig. & Statistic & Df & Sig. \\
\hline Motivation & 0.188 & 98 & 0.000 & 0.925 & 98 & 0.000 \\
\hline Fluency & 0.170 & 98 & 0.000 & 0.894 & 98 & 0.000 \\
\hline Curiosity & 0.138 & 98 & 0.000 & 0.937 & 98 & 0.000 \\
Interaction & 0.138 & 98 & 0.000 & 0.932 & 98 & 0.000 \\
\hline
\end{tabular}

The Kolmogorov-Smirnov and Shapiro-Wilk results showed a statistical difference among all four variables ( $\mathrm{p}$ $=.000)$, which means that the null hypothesis must be rejected. These results show an influence over the data, and this influence is the use of L1 text in a class. The plotted data in Figure 1 indicate a non-normal distribution.

\section{Motivation}

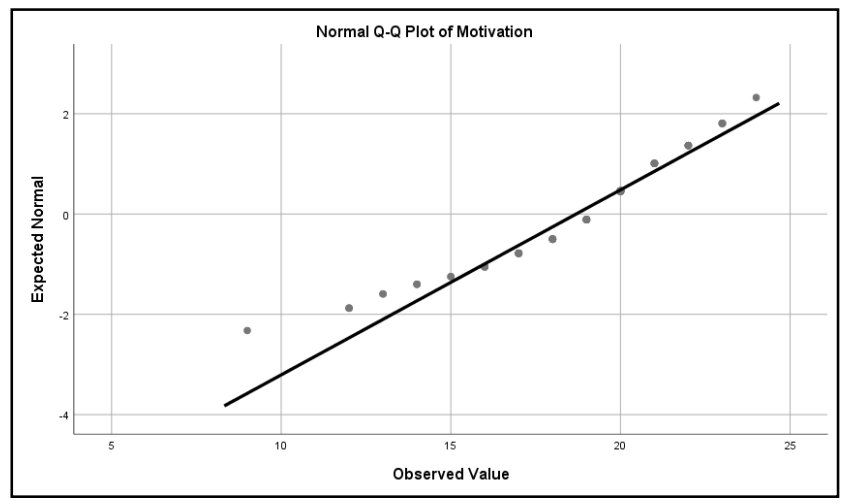

Interaction

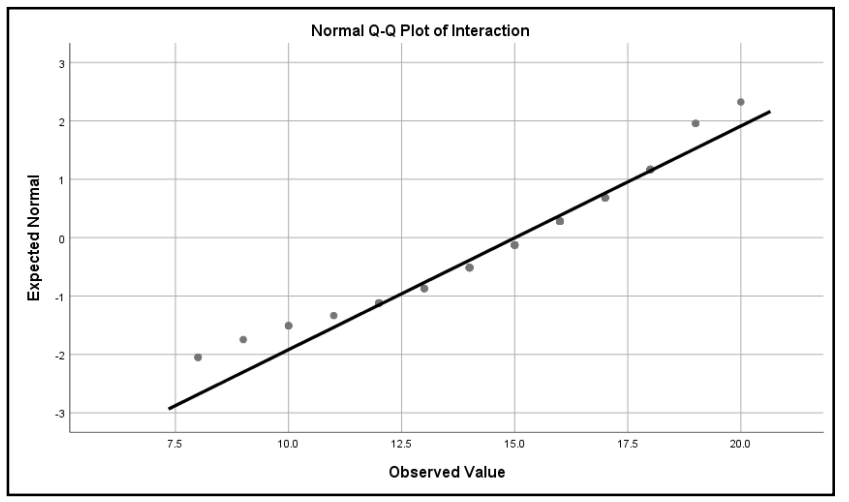

Fluency

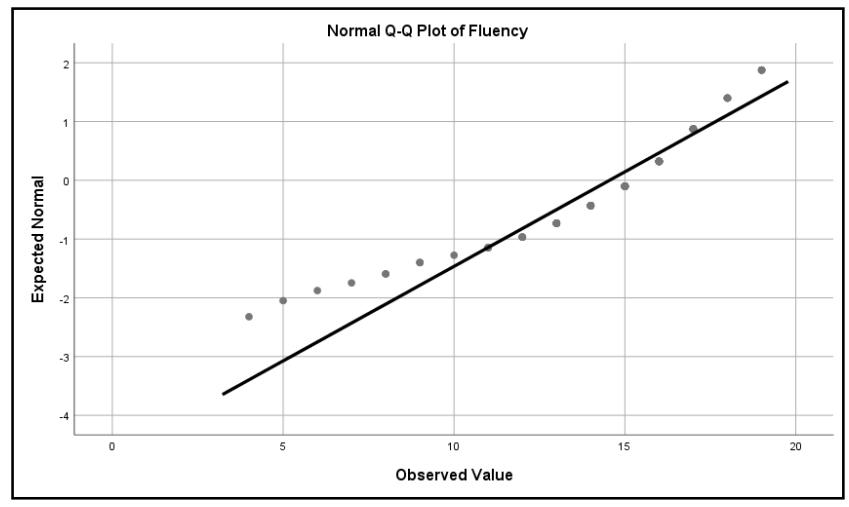

Curiosity

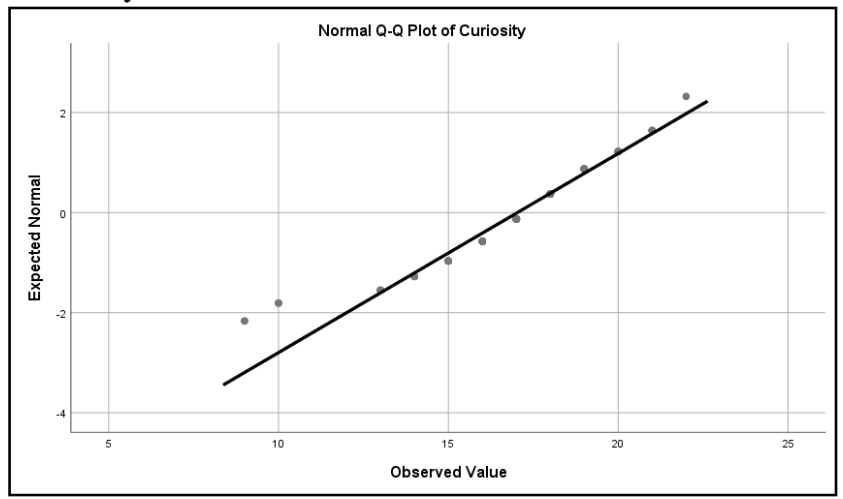

Figure 1. Motivation, Fluency, Interaction, and Curiosity

The preliminary analyses were performed to ensure that no violation of assumptions of normality, linearity, and homoscedasticity was found (see the normality test above). However, there was a non-normal distribution, which means that the null hypothesis was rejected. Thus, Pearson correlation was run; see Table 6 for the results. 
Table 6. Correlation Matrix for the Dependent Variables

\begin{tabular}{|c|c|c|c|c|c|}
\hline \multicolumn{6}{|c|}{ Correlations } \\
\hline & & motivation & Fluency & interaction & curiosity \\
\hline \multirow[t]{3}{*}{ motivation } & Pearson Correlation & 1 & $.375^{* * *}$ & $.308^{* *}$ & $.267^{* *}$ \\
\hline & Sig. (2-tailed) & & .000 & .002 & .008 \\
\hline & $\mathrm{N}$ & 98 & 98 & 98 & 98 \\
\hline \multirow[t]{3}{*}{ fluency } & Pearson Correlation & $.375^{* * *}$ & 1 & $.682^{* *}$ & $.616^{* * *}$ \\
\hline & Sig. (2-tailed) & .000 & & .000 & .000 \\
\hline & $\mathrm{N}$ & 98 & 98 & 98 & 98 \\
\hline \multirow[t]{3}{*}{ interaction } & Pearson Correlation & $308^{* *}$ & $.682^{* *}$ & 1 & $.569^{* *}$ \\
\hline & Sig. (2-tailed) & .002 & .000 & & .000 \\
\hline & $\mathrm{N}$ & 98 & 98 & 98 & 98 \\
\hline \multirow[t]{3}{*}{ curiosity } & Pearson Correlation & $267^{* * *}$ & $.616^{* * *}$ & $.569^{* * *}$ & 1 \\
\hline & Sig. (2-tailed) & .008 & .000 & .000 & \\
\hline & $\mathrm{N}$ & 98 & 98 & 98 & 98 \\
\hline
\end{tabular}

Table 6 shows the correlation matrix among the independent variables used in the study. The relationship between the variables motivation to learn English (as measured by motivation) and fluency (as measured by the scores of L1 text), as well as that between L1-L2 interaction (as measured by the language scores) and curiosity to learn the L2 language and culture (as measured by the scores of L1 text), was investigated using the Pearson correlation coefficient. There was a positive correlation between the variables under investigation; the association between motivation to learn English and fluency was $(\mathrm{r}=0.375, \mathrm{n}=98, \mathrm{p}<0.000)$, while that between curiosity and L1-L2 interaction was $(\mathrm{r}=0.569, \mathrm{n}=98, \mathrm{p}<0.000)$. These results imply that increased exposure to $\mathrm{L} 1$ text increased motivation to learn English and fluency while the L1-L2 interaction increased the curiosity.

\section{Discussion}

According to the study results, the students believed that the use of L1 text in L2 class would improve motivation and fluency and increase curiosity. The results yielded by the data analysis showed that problem-based learning and the benefits of L1 text received positive perceptions from most students. The results of the normality test showed a violation of the assumption of normality. Homoscedasticity was related to the assumption of normality of the variables; however, when the results of the variables were found to be non-homoscedastic, the variables were concluded to be related to an outlier influence that transformed the variables. In this research methodology, precautions were taken to eliminate all variables that could affect the outcome of this study, leaving only L1 text as a potential influence. The descriptive statistics confirmed the effect of using L1 Korean classical novels in the class.

The research confirms that L1 text enhances the learner's motivation and language development. In doing so, L1 speakers become more flexible and engaged in linguistic diversity and variation in their classrooms, including the entire repertoire of the students. Dewey (1916) said, "We do not learn from experience...we learn from reflecting on experience. Furthermore, when learning a new language (L2)", students neither compartmentalize their dominant language (L1) nor exclude their L1 repertoire. Therefore, L1 text can contribute to motivating students to learn English.

Furthermore, L1 text allows all students to engage in learning activities, because they are immersed in the learning process. This active engagement allows students to form rich and memorable experiences. In other words, L1 text is used to "put students in touch with some of the more subtle and varied creative uses of language" (McIver \& Park, 2020; Shazu, 2014, p. 30). Therefore, L1 text is a great tool to build a learner's motivation, fluency, and cultural curiosity toward the L2 language.

The students in this study also reported that L1 text improved their motivation to learn English and fluency. The students exhibited increased motivation toward the L2 language when L1 text was used in the class. In addition, they believed that using L1 text in an L2 class would be beneficial. Drawing on symbolic representation (Bruner, 1966), the students believed that using L1 text in the class would assist in explaining and developing vocabulary, developing concepts, and improving knowledge.

The increase in motivation and fluency was evident in the vocabulary used and the social topics discussed in the project-based task. Examples are shown in Table 7. 
Table 7. Examples of Vocabularies and Social Topics

\begin{tabular}{|c|c|c|}
\hline Class & Vocabularies & Social topics \\
\hline Beginner Speaking & $\begin{array}{l}\text { aristocrats, immoral, insightful, } \\
\text { perceived, cultural connotations, } \\
\text { populist, inequities, etc. }\end{array}$ & $\begin{array}{l}\text {-socio-economic classes }(<\text { Yanbanjeon }\rangle) \\
\text {-historical changes of immorality and political corruption in Korea } \\
(<\text { Hojil }\rangle) \\
\text {-economic situation in Korea }(\langle\text { Heosangjeon }\rangle)\end{array}$ \\
\hline Intermediate Speaking & $\begin{array}{l}\text { Hypocrisy, class envy, oppression, } \\
\text { bribery, indoctrination, virtue, } \\
\text { embezzlement, etc. }\end{array}$ & $\begin{array}{l}\text {-economic structure, commercial distribution (related to COVID-19) } \\
(<\text { Heosangjeon }>) \\
\text {-Educators' morality in today's society }(<\text { Hojil }>) \\
\text {-Business people's morals ( }<\text { Yangbanjeon }\rangle)\end{array}$ \\
\hline
\end{tabular}

During the problem-based learning assignment, the beginner students increased their vocabulary used in the classroom (e.g., aristocrats, immoral, insightful, perceived, cultural connotations, populist, and inequities). These words are used in the L1 language by students in academic and social settings; however, by incorporating L1 text in L2 classroom, the students could express their previously learned knowledge of the subject matter and delve into the true meaning of the L1 novels and the current Korean society. In addition, when comparing the cultural issues of Korean and American societies, the students' curiosity toward American culture was increased.

The topics used in the discussion related to the three novels were insightful and extraordinary for beginner students in an EFL classroom. For example, when the students discussed Yangbanjeon, they talked about socio-economic classes in the novel and today's society. They stated that there remain huge gaps between the upper and lower classes; upper classes can have power, privilege, and advantages, as well as better job opportunities, over lower classes in education. They also believed that today's society did not consider these gaps, which is its main problem. When discussing Hojil, the students focused on the historical changes in immorality and political corruption in Korea's society. They discussed the growth of inequity in society, the rise of populist political figures, and the future direction of Korean society. Finally, when discussing Heosangjeon, the students focused on how today's economic situation focuses on large corporations (e.g., Samsung, LG, and Hyundai) and not entrepreneurs. The government provides tax advantages to large companies to foster overseas trade while not assisting small business owners. The students in this study delved into social inequities in society using the vocabulary not traditionally used in a beginner class; however, they did not expand topics to the Western world situation.

While addressing the problem-based learning assignments, the intermediate students also incorporated higher vocabularies that were not typically used (e.g., hypocrisy, class envy, oppression, bribery, indoctrination, interpenetration, and embezzlement) in an EFL classroom. For example, "hypocrisy" in Yangbanjeon: the students drew on their L1 repertoire to understand various concepts using this vocabulary. In the societal discussion, the students talked about the movie Parasite, which presented the dark sides of upper and lower classes of the Korean society, as well as the hypocrisy of today's society. The students also talked about societal hypocrisy, such as being successful if they attend a prestigious university or being rich if they work hard; in reality, it is the opposite in many cases.

The students also discussed bribery and corruption without the threat of criminal repercussions in Heosangjeon. The students focused on the morals of Koreans: how they focused on the good of society and not the failures of an individual. They believed that, the society can be safeguarded if taught virtues. Under the social and political turmoil, the students focused on the well-being of others. It is the most wonderful quality of Korean culture. In Hojil, students focused more on indoctrination education, wherein some class lectures are given and opinions are not accepted. Many Korean students are reluctant to talk negatively about their educators, as they have high respect for education; however, the students in this study talked about today's educators' attitudes and wondered if Korean education was going in the right direction, if change was necessary, or if scholars are becoming hypocrites, like Bukkwak in the novel. In brief, using the new vocabulary shows that L1 text can facilitate a social discussion among students and improve their motivation, fluency, and interaction with L1 in an EFL/ESL class. In addition, according to the descriptive statistics, the students believed that motivation $(\mathrm{M}=3.76, \mathrm{SD}=.600)$ and fluency $(\mathrm{M}=3.63, \mathrm{SD}=.776)$ would increase with the use of L1 text.

The remaining point to discuss in this chapter is curiosity. As seen in Chapter 3, curiosity showed the lowest mean and standard deviation of all data in the statistical analysis. This is exciting, and there could be many reasons for this, such as the usage of L1 text restricting students to expand their thoughts, lack of students' understanding or motivation about Western culture, or lack of instructors' guidance to explore Western and Korean cultures. The 
exciting thing here is that the students focused primarily on Korean culture, even if the teachers mentioned not restricting their views on Korean culture and society. This issue should be explored in depth over time.

The use of L1 text as an instructional methodology should lead students toward self-discovery and language learning; it should emphasize discovery and invention. The students should not only expand their knowledge but also interact within society. Students use L1 text to facilitate their comprehension process and to reduce any insecurities that might arise from their limited language proficiency. Instructors use L1 to consolidate students' knowledge of English, such as vocabulary, sentence structures, and social aspects.

Note that teachers' appropriateness and quantity of L1 text use cannot be universally defined. It depends on students' proficiency levels and the instructor's purposes. L1 should be used as a creative expression, where language can be constructed to create knowledge. Reflection on language use should be included in all problem-based learning activities. This can be achieved by objectifying products as the externalization of cognition in the expression activities. Dialogue in the classroom builds school cultures that operate as mutual communities of learners, all contributing to educating one another (Bruner, 1996). It does not simply foster cognitive competence but also promotes the social side of learning related to motivation and social inclusion. The use of L1 can facilitate the acquisition of new information, transformation, and evaluation.

Insofar, as we have adopted the image of such learners as an aim of school education, we can understand the importance of the spiral curricula, or Brunner's (1979) claim: "We opt for depth and continuity in our teaching, rather than coverage." Furthermore, in Bruner's (1996) view of learning, active learning must make learners understand everything from only one aspect. Bruner (1979) studied the dialectic between the past and present, the possibilities in the interaction between human beings and cultures, and the duality of acquiring and creating learning.

\section{Conclusion}

The use of L1 text in an EFL class directly contrasts with the traditional norms endorsing language learning. It is important to accept that individuals are not and cannot be equally competent in two or more languages. L2 must be complementary and integrated into bilingual/multilingual programs. Therefore, students' first language, L1, should support learning in L2. Many questions remain about the use of L1 text in teaching pedagogies, especially regarding its implementation and outcomes.

The first question is regarding scaling from L1 culture to worldwide culture (including L2 culture). As seen in other articles cited above, students talk highly about Korean society and culture but hardly about worldwide culture. To improve L2 language generally, it is imperative to let students expose themselves to L2 culture. For this purpose, professors' pedagogical strategies to lead students to include worldwide topics in their discussions, including understanding L1 text and its proper classroom practices, are necessary.

Second, we need to explore the possibility of using other genres and hybrid L1 text (translated into English). As seen in this study, the use of classical novels as L1 text was instrumental in improving students' motivation, fluency, and interaction, and increasing curiosity. This is because novels have a solid storyline with many social implications and debatable issues for individuals. In addition to classical novels, many other genres can be used as L1 text, such as modern novels, comics, play scripts, political speeches, and historical documents. There are differences between genres, but they can be found using L2 text as an assistant of L1. In addition, multidisciplinary genres can influence the results, and researching them will be an interesting avenue of future research.

Third, we need to consider various educational pedagogical experiments, such as task-based learning, communicative learning, and flipped learning. Each pedagogy can affect students' outcomes differently. Therefore, a strict methodological procedure should be implemented to ensure consistent results regarding L1 text's effectiveness.

Finally, the effects of multicultural classrooms must be considered as well. Multicultural students present a unique situation, unlike monolingual students. In this study, the use of classical literature as L1 text was highly effective for monolingual students; however, this does not mean that it will work for multicultural students as well. Nowadays, many instructors face multicultural students in the classroom. Therefore, to improve these students' L2 language abilities, finding the correct text and pedagogy is essential. This remains a massive issue in this field and will be part of our future research, along with other issues.

\section{Limitation}

Although this study has presented several students' perspectives on the use of L1 text and their perception of the use of Korean Classical novels in an EFL classroom, the ideal situation would be to have data on how the students perform in class, using the L1 text over the entire semester, including a pretest-posttest study. Furthermore, future 
research could look more into how second language anxiety is presented in the English classrooms in a Korean university and how this affects the students' second language identities.

\section{Declaration of conflicting interest}

The author declares no potential conflict of interest with respect to the research, authorship, and/or publication of this article.

\section{Funding}

The authors received no financial support for the research, authorship, and/or publication.

\section{References}

Abiria, D. M., Early, M., \& Kendrick, M. (2013). Plurilingual pedagogical practices in a policy constrained context: A northern Ugandan case study. TESOL Quarterly, 47(3), 567-590. https://doi.org/10.1002/tesq.119

Abrahamsson, N. (2009). Andraspråksinlärning. Lund: Studentlitteratur.

Alsaawi, A. (2020). Plurilingualism and Monolingualism in Foreign Language Classrooms: The Perspective of EFL Teachers in Saudi Arabia. Journal of Language and Cultural Education, 8(1). https://doi.org/10.2478/jolace-2020-0002

Bialystok, E. (2001). Bilingualism in development: Language, literacy \& cognition. Cambridge University Press. https://doi.org/10.1017/CBO9780511605963

Boeckmann, K. (2012). Promoting plurilingualism in the majority language classroom. Innovation in Language Learning and Teaching, 6(3), 259-274. https://doi.org/10.1080/17501229.2012.725253

Bronfenbrenner, U., \& Morris, P. A. (1998). The ecology of developmental processes. In W. Damon \& R. M. Lerner (Eds.), Handbook of child psychology: Theoretical models of human development (993-1028). John Wiley \& Sons Inc.

Brunner, J. (1966). Toward a Theory of Instruction. Harvard University Press.

Brunner, J. (1979). On Knowing, Essays for the Left Hand. Harvard University Press.

Brunner, J. (1996). The Culture of Education. Harvard University Press.

Chimbganda, A. B., \& Mokgwathi, T. S. (2012). Code-switching in Botswana's ESL classrooms: A paradox of linguistic policy in education. International Journal of English Linguistics, 2(2), 21-32. https://doi.org/10.5539/ijel.v2n2p21

Cohen, J. (1988). Statistical Power Analysis for the Behavioral Sciences (2nd ed.). Lawrence Erlbaum Associates, Publishers.

Cook, V. (2001). Using the first language in the classroom. The Canadian Modern Language Review/La Revue Canadienne Des Langues Vivantes, 57(3), 402-423. https://doi.org/10.3138/cmlr.57.3.402

Cummins, J. (2017). Teaching for Transfer in Multilingual School Contexts. In O. García et al (Ed.), Bilingual and Multilingual Education. 1 ed., 103-116. Springer International Publishing. https://doi.org/10.1007/978-3-319-02258-1_8

Dawson, S., Tan, J. P. L., \& McWilliam, E. (2011). Measuring creative potential: Using social network analysis to monitor a learner's creative capacity. Australasian Journal of Educational Technology, 27(6), 924-942. https://doi.org/10.14742/ajet.921

Dewey, J. (1916). Democracy and Education. EdTech Books.

Dicamilla, F., \& Antón, M. (2012). Functions of L1 in the collaborative interaction of beginning and advanced second language learners. International Journal of Applied Linguistics, 22(2), 160-188. https://doi.org/10.1111/j.1473-4192.2011.00302.x

Ekman, S. (2015). Teacher beliefs on using Swedish in the teaching of English. Lund University.

García, O., \& Li, W. (2014). Translanguaging: language, bilingualism and education. Basingstoke, Hampshire: Palgrave Macmillan. https://doi.org/10.1057/9781137385765

García, O., \& Seltzer, K. (2016). The Translanguaging Current in Language Education. In B. Kindenberg (Ed.). Flerspråkighet som resurs: symposium 2015. (1 ed., 19- 30). Stockholm: Liber.

Gort, M. (2006). Strategic codeswitching, interliteracy, and other phenomena of emergent bilingual writing: Lessons 
from first grade dual language classrooms. Journal of Early Childhood Literacy, 6(3), 323-354. https://doi.org/10.1177/1468798406069796

Gort, M., \& Pontier, R. W. (2013). Exploring bilingual pedagogies in dual language preschool classrooms. Language and Education, 25(3), 223-245. https://doi.org/10.1080/09500782.2012.697468

Heinzmann, S., \& Hoti, A (2012). Foreign language reforms in Swiss primary schools: Potentials and limitations. In Braunmüller, K., \& Gabriel, C. (Eds.) Multilingual individuals and multilingual societies (pp. 189-205). Amsterdam: John Benjamins Publishing Company. https://doi.org/10.1075/hsm.13.13hae

Iannacci, L. (2008). Beyond the pragmatic and the liminal: Culturally and linguistically diverse students' code-switching in early-years classrooms. TESL Canada Journal/Revue TESL Du Canada, 25(2), 103-123. https://doi.org/10.18806/tesl.v26i1.132

Karlsson, A., Nygård, L. P., \& Jakobsson, A. (2016). Flerspråkighet som en resurs i NO-klassrummet. Pedagogisk Forskning i Norden, 21(1-2).

Lee, S. (2007). Language policy in a Korean-English two-way immersion setting. Language, Culture and Curriculum, 20(2), 109-125. https://doi.org/10.2167/lcc329.0

Manyak, P. C. (2006). Fostering biliteracy in a monolingual milieu: reflections of two counter hegemonic English immersion classes. Journal of Early Childhood Literacy, 6(3), 241-266. https://doi.org/10.1177/1468798406069798

Mazak, C., \& Carroll, K. S. (2017). Translanguaging in Higher Education: Beyond Monolingual Ideologies. Bristol: Multilingual Matters. https://doi.org/10.21832/9781783096657

McIver, P., \& Park, S. Y. (2020). Using Classical Literature in EFL/ESL Classrooms to Improve Student Motivation and Achieve Linguistic Proficiency. The Journal of Asia TEFL, 17(4). https://doi.org/10.18823/asiatefl.2020.17.4.20.1439

Moore, E. (2016). Conceptualizing multilingual higher education in policies, pedagogical designs and classroom practices. Language, Culture \& Curriculum, 29(1), 22-39. https://doi.org/10.1080/07908318.2016.1132652

Park, J. W. <Heosangjeon> in, 「Okkhapyahwa」，『Yeolhailgi(熱河日記)』(II)(Classic Korean translation series No. 19), Korean Classics Research Institute, 1968, pp. 310 314.

Park, J. W. 〈Yangbanjeon>, in 「Banggyeonggakuijeon」, 『Yeonahmjib(燕撖集)』 lower volume, Dolbegae, 2007, pp. 186-191.

Park, J. W. <Hojil> in, 「Gwannaejeongsa」, 『Yeolhailgi(熱河日記)』(I)(Classic Korean translation series No.18), Korean Classics Research Institute, 1968, pp. 186 191.

Shazu, R. I. (2014). Use of literature in language teaching and learning a critical assessment. Journal of Education and Practice, 5(7), 29-35.

Storch, N., \& Wigglesworth, G. (2003). Is there a role for the use of the L1 in an L2 setting. TESOL Quarterly, 37(4), 760-770. https://doi.org/10.2307/3588224

Swain, M., \& Lapkin, S. (2000). Task-based second language learning: The uses of the first language. Language Teaching Research, 4(3), 251-274. https://doi.org/10.1177/136216880000400304

Tabatabaei, R. (2019). Translanguaging in ESL classrooms in Sweden: from the students 'point of view.

Varghese, M. M. (2008). Using cultural models to unravel how bilingual teachers enact language policies. Language and Education, 22(5), 289-306. https://doi.org/10.1080/09500780802152671

\section{Copyrights}

Copyright for this article is retained by the author(s), with first publication rights granted to the journal.

This is an open-access article distributed under the terms and conditions of the Creative Commons Attribution license (http://creativecommons.org/licenses/by/4.0/). 